"The submitted manuscript has been authored by a - contractor of the U.S. Government under contract No.

DE-AC05-96OR22464. Accordingly, the U.S.

Government retains a nonexclusive, royalty-free license to publish or reproduce the published form of the

contribution, or allow others to do so, for U.S.

Government purposes."

\title{
FEEDBACK FROM USERS OF ENERGY EFFICIENCY INFORMATION ON THE INTERNET: ANALYSIS OF THE U.S. CADDET HOME PAGE
}

\section{SUMMARY}

\author{
by Marilyn A. Brown and Melissa K. Voss \\ oak Ridge National Laboratory*
}

This paper describes the U.S. experience to date with providing energy efficiency information from the Center for the Analysis and Dissemination of Demonstrated Energy Technologies (CADDET) on the Internet. The paper begins by describing the way that information is displayed in the U.S. CADDET home page system. Statistics are then provided on numbers and types of users of the home page. Next we describe the frequency with which different types of CADDET information have been accessed and summarize the feedback provided by users. Drawing on this experience with the U.S. CADDET home page system, the authors conclude that energy efficiency information systems on the World Wide Web can contribute significantly to the goals of CADDET and other information outreach programs. However, to reach a wider range of audiences, Internet systems need to be supplemented by other dissemination efforts aimed at reaching individuals in countries and organizations that are not currently using Internet services. In addition, more personal and customized information sources are needed to provide users with the types of assistance and guidance that may be required to translate knowledge of a technology's technical and financial performance, into a decision to adopt the technology.

\section{DISCLAIMER}

\footnotetext{
This report was prepared as an account of work sponsored by an agency of the United States Government. Neither the United States Government nor any agency thereof, nor any of their bility for the accuracy, completeness, or implied, or assumes any legal liability or responsiprocess disclosed, or represents that its use ulness of any information, apparatus, product, or ence herein to any specific commercial use would not infringe privately owned rights. Refermanufacturer, or otherwise commercial product, process, or service by trade name, trademark, mendation, or favoring by the not necessarily constitute or imply its endorsement, recomand opinions of authors expressed herein United States Government or any agency thereof nocessarily state or reflect those of the
} 


\title{
FEEDBACK FROM USERS OF ENERGY EFFICIENCY INFORMATION ON THE INTERNET: ANALYSIS OF THEU.S. CADDET HOME PAGE
}

\author{
by Marilyn A. Brown and Melissa K. Voss
}

The use of inter-networked computers offers organizations the ability to reach potentially vast audiences with minimal effort, by taking advantage of the huge investments being made in dectromic commurications infrastructure worldwide. While on-line communications represents only a small fraction of today's domestic and international communications, they are expending at an unprecedented pace and are transforming domestic and global information flows.

Many businesses and consumers are taking atvantage of this communication potential by connecting to the Intemet-a system by which computers can communicate with one another using commonly acepted protocols. According to a Nielsen Media Research (1995) survey, approxinately 24 million people in the U.S. and Canada (or almost $11 \%$ of the 16-and-older population in North America) are Internet users.

Every month, tens of thousands of businesses and households buy direct Internet connections or purchase sabscriptions to m-line information and communication services. It has been estimated that by the year 2000 there will be 180 million Internet users worldwide (Verity and Hof, 1994).

Organizations place information on the Intemet by creating home pages on the World Wide Web-a system that graphical in to simplify the tasks of searching for and retrieving information. This paper scribes the U.S. experience to date with the Internet home page for the Center for the Analysis and Dissemination of Demonstrated Energy Technologies (CADDET)-

The paper begins by describing CADDET and the U.S. CADDET home page system. Statistics are then provided on uers of the lorre page, including the number of times the home page has been accessed each mont sinee its inception, and the types of users of the information-by country of origin and organizational affiliation. Next we describe the frequency with which different types of CADDET information have been accessed and the feedback provided by uses who completed "electronic coupons." The paper ends with a discussion of its findings.

\section{BACKGROUND ON CADDET}

The Center for the Analysis and Dissemination of Demonstrated Energy Technologies was formed by the Intermationd Energy Agency in 1988 to collect and disseminate information on demonstration projects that have produced data on the successful economic and technical performance of energy-efficient end-use technologies. The 
Center recognizes that the tangible evidence of technical and economic viability produced by demonstration projects can effectively accelerate the replication of successful technologies.

In 1993 CADDET was expanded and now has two branches-CADDET Energy Efficiency and CADDET Renewable Energy. In the United States, involvement with the CADDET Energy Efficiency Annex is coordinated by Oak Ridge National Laboratory for U.S. Department of Energy (DOE). The National Renewable Energy Laboratory provides technical support for U.S. involvement in the CADDET Renewable Energy Annex.

At the heart of the CADDET operation is a computerized Register of information on more than 1,600 energy technology demonstration projects. Each of the 15 countries that belong to CADDET have contributed Register entries describing demonstrations in their countries. A majority of these entries focus on technologies for increasing the efficiency of energy use in buildings and industrial processes. Agriculture, transportation, utilities, and other end uses are also represented, but to a lesser degree. A total of 358 entries describe U.S. demonstration projects.

CADDET also produces technical brochures, which provide expanded information on key technologies represented in the CADDET Register. Each brochure describes the technology being demonstrated, the setting, the cost of the project and the energy saved, other findings concerning the operation of the technology, and individuals who can be contacted for further information. The most in-depth of the CADDET products are the Analysis Reports. These reports use experts from all CADDET member countries to compare the technical and economic results of selected demonstration projects on a particular technology. Sixteen analysis reports have been produced to date. Finally, CADDET also produces quarterly Newsletters, which are currently distributed to over 10,000 subscribers world-wide. Each issue focuses on a specific technical topic and features international articles, news items, abstracts of recent publications, and meeting notices.

\section{CADDET INFORMATION ON THE INTERNET}

A range of traditional promotional techniques are employed by the DOE, ORNL, and the U.S. CADDET National Team to make potential audiences aware of the energy efficiency information available from CADDET. In addition, in November of 1994, the United States became the first CADDET member country to make CADDET information available on the Internet. The address for the the U.S. CADDET-energy efficiency home page is:

\section{HTTP://www.ornl.gov/CADDET/caddet.html.}


The U.S. CADDET home page (Figure 1) allows users to view all of their options before beginning a customized search. In particular, links to five additional pages are listed and described.

- By selecting the first page, "About CADDET," users are provided background information on CADDET, including an overview of the Center's goals, information products, and organizational structure (Figure 2).

- The second page introduces users to the CADDET database of information on demonstration projects (Figure 3). From there, the user can elect to conduct a query of the 358 entries that describe the technical and economic performance of energy efficiency technologies demonstrated in the U.S. For instance, a search for the term "motor" in the abstract of the U.S. entries identified 14 projects (Figure 4). From that point, the user could access the abstract and full documentation for each of these 14 entries.

- The third page provides an overview of CADDET brochures, including an explanation of the distinction between "CADDET demonstration brochures" and "CADDET results brochures" (Figure 5). A listing of all of these brochures can then be provided by clicking on either type of brochure (see Figure 6 for an example). At this time, users must contact ORNL to obtain copies of the individual brochures. (All of the brochures are available free-of-charge to U.S. users, but only the U.S. brochures are available for free to international users). The U.S. intends to place the text of all of its future brochures onto the Internet.

- CADDET analysis reports are the subject of the fourth page. Here, the user can obtain a list of the 16 analysis reports that have been published to date (Figure 7), along with information about how to purchase them. In addition, a short abstract of each report can be accessed, such as the summary of "Industrial Drying Technologies," which is shown in Figure 8.

- Finally, the user may elect to complete a CADDET End-user Form (Figures 9 and 10). This form, also called an "electronic coupon" asks users to provide feedback about CADDET information and offers them a chance to request additional information.

The pages shown in Figures 5 through 8 were added to the CADDET home page system on December 15. Thus, the usage figures for these pages presented below are based only on a half-month period of Internet accessibility. 
Fig. 1

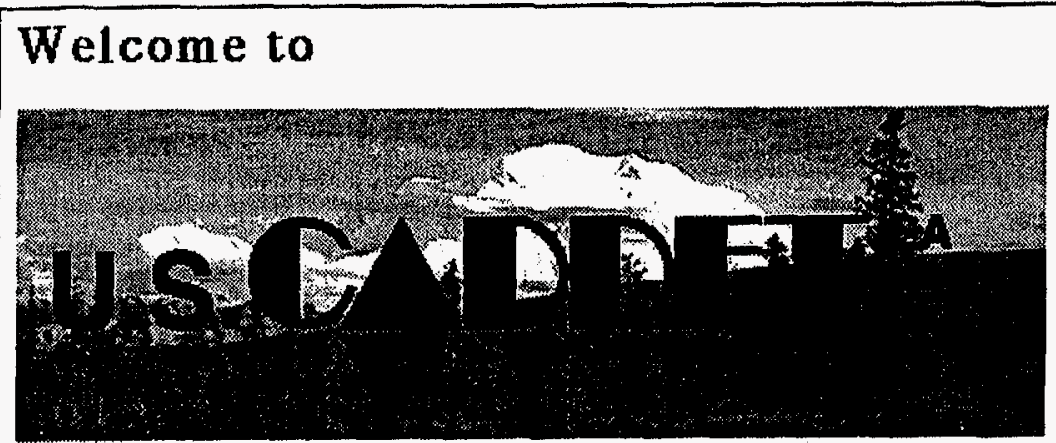

Center for the Analysis and Dissemination of Demonstrated Energy Technologies (CADDET)

CADDET is an Intemational Energy Agency program responsible for collecting and disseminating information on demonstrated, energy efficient and rene srable energy technologies. The program focuses on demonstration projects on full-scale applications of new technologies. By utilizing information from this intermational infomation network, you can find out what energy-efficient and renewable energy technologies have worked in other countriez and how you can benefit from their application. You can also submit projects on demonstrated energy-saving technologies to be reviewed as potential CADDE'T products.

There are two branches of CADDET: CADDET Energy Efficiency and CADDET Renewable Energy. Oak Ridge National Laboratory is the U.S. Support Office of CADDET Energy Efficiency and the National Rene wrable Energy Laboratory is the U.S. Support Office of CADDET Renewable Energy. There are currently 15 member countries participating in CADDET Energy Efficiency and 12 member countries participating in CADDET Rene wrable Energy. U. S. participation in CADDET is sponsored by the Department of Energy,

\section{Alout CADDET}

Tle CADDET Danhse, The Regisler

\section{The CADDET Brothure}

\section{The CADDET Amalysis Penons}

\section{The CADDET Eul-user Fon}

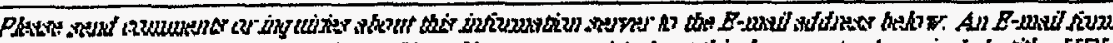

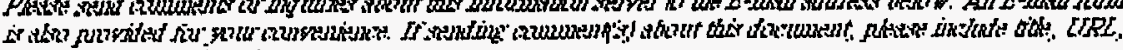

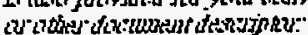

info_servers@oml.gov

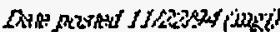

Fig. 2

\section{About CADDET}

CADDET's objective is to brosden and improve the exchange of information on energy-saving technologies that have been demonstrated in applications in industry, buildings, transportation, utilities, and agriculture.

CADDET was founded in 1988, as a program focused on energyefficient technologies. In 1993, CADDET expanded into wo branches: CADDET Energy Efficiency and CADDET Rene wable Rnergy. CADDET Energy Efriciency is based in The Netherlands and now has fitteen member counthes. Australia, Belgium, Canada, Dermark, Filand, Itajy, Japan, The Necherlands, New Zealand, Norway, The Republic of Korea, Sweden Switzerland, the United Kingdom, and the Unined States. CADDET Renewable Energy is based in the United Kingiom and now has twelve member counties. Austalla, Denuark, Filand, Japan, The Republic of Korea, The Netherlands, New Zealand, Norway, Streden, Switzerland, the United Kingdom, and the United States.

Each CADDET member country contributes information on demonstrated energy-efficient and/or renewable energy technologies. Each CADDET Center then disseminates the results of these demonstrations back to the member countries via these products: brochures on individ ual projecs, a quarterly ne wrsleter, analysis reports, and a computer-based register of demonstration projects.

The U.S. Support Office for CADDET Energy Efficiency is Oak Ridge National Laboravory. The U. S. Suppon Office for CADDET Rene wrable Energy is the National Rene wable Bnergy Laboratory. U.S. participation in CADDET is sponsored by the Depatment of Energy, Office of Technical and Financial Assistance.

Each CADDET member country has established a Natonal Team. The U.S. National Teams for Energy Efficiency and Renewrable Energy are compnised of representatives from techical and professional organizations; private ind ustry; utilites; and local, state, and federal agencies. The U.S. Support Offices collaborate whth the U.S. National Teams to facilitate marketing CADDET products, and to gather information and leads on outstanding demonstrated energy technology projects. The U.S. Support Offices also respond to a

If you vould like information sent to you on how to obtain CADDET pmducts or how to submit project information for review as a potential CADDET product, please complete the CADDET End-user Fom

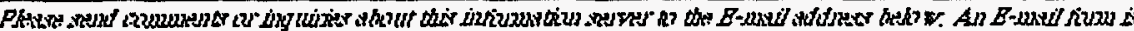

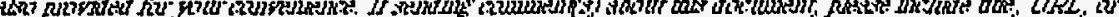

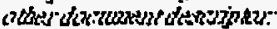

mfo_servers@oml.gov

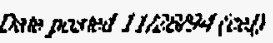


Fig. 3

\section{CADDET (see description below)}

Compleve ext seanch terms:

Clear Form

Fielded search teras

title:

abstract:

project:

brochure:

\section{Description:}

The CADDET Database, The Register

The CADDET Register is a user-friendly database of demonstration projects on energy-efficient and renewable energy technologies. The full Register contains glmost 1700 neconds contributed by CADDET member counmes. This partial listing contains the $358 \mathrm{U}$. S. contributed reconds to the Register. The Register is one of Mavowablo enotry projocts.

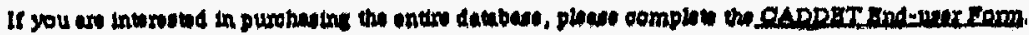

The WAIS databese on thes server contains the rollowing flelds:

Title - Project tite

Project - Project number

Brochure - CADDET brochure number

Abstract - Abstract of project

You may either search on any combination of the fields listed above, or perform a compleve vext search on the full text of the documents. If you need help in using this database, a tutorial on Perfoming. WHAIS Searches is arailable

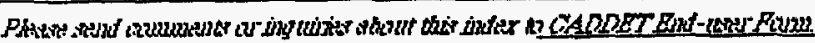

Fig. 4

\section{Results from running query with: motor}

To inclade the next of one of the folloving documents in anather search, check the appropriave bor(es) and then submit another query nsing the form at the bottom of this page.

$\square$ Svine_farm_digester_generates_bio-gas_to__un_a_motor_zenerator_set (HTML) Score: 1000, Bytes: 1948

$\square$ Food_processing_company_uses_adjustable_speed_drives_Q_control_motor_speed_of_blenders

$\square$ Electric_induction_Heating_of Thermoset Adhesives in_motor_ind ustry (HTML) Score: 744, Bynes: 4839 $\square \frac{\text { Stirling engine_goeg commencial_for_mobile_home_auxiliary_power }}{\text { (HTML) Scone: } 431, \text { Bytes: } 2337}$

$\square$ Energy_analysis_and_implemented measunes_result in energy_zarings (HTML) Score: 413 Bytes: 8825

$\square$ Yariable_frequency_adjustable_speed_drives_control induced-draft_fons in pulp_and paper processes (HTML) Score: 379 , Bytes: 462

$\square$ Gas-fined_rethemalising_open_used_for_institutional_and_commencial_high-volume_food_preparation (HTML) Score: 370, Bynes: 5153

$\square$ Capacity_optimisation of HYAC_sysuem_hyd onic_fows_in municipal_buildings (HTML) Score: 369 , Bytes: 5450

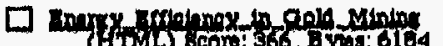

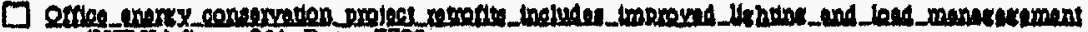
(HTML) Scont: 361 , Byhos: 5798 $\square$ Project ROSE Educales Public_About Used_Oil_Colloction_and_Recycing

$\square$ New_Rootop_Handiling_Unit__and_R_Tro-Swge_Air_Eulmation_System_Saves_Energy_in_bullatings (HTML) Scose: 356, Byhes: 646 ?

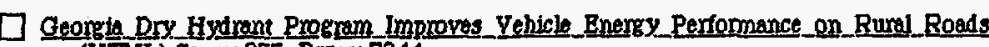
(HTML) Score: 355 , Bytes: 7344

口 Agricultural_Energy_Conservation Through_Conservation Tullage,_Ingation_Mongement and_Ecofollow (HTML) Score: 355 , Bytes: 7721

$\square$ The_SHOMAX(R)_Enhanced_Natural_Thermal_Storage_(SENTS)_Ice-Pond_System (HTML) Score: 346 , Byres: 8008

$\square$ Query Report for this Search (TEXT) Score: 1 , Bytes: 874

\section{CADDET}


Fig. 6

\section{CADDET BROCHURES}

\section{OCTOBER 1995}

CADDET brochures present the results of demonstrations of selected energy technologies to highlight significant

Designed ov assist end-users, each brochure gives a comprehensive description of the project illustrated with phorographs and diagrams. The aims and background to the project are given with a description of the rechnology, are also included.

More than 200 brochures are amilable to dare, and approximately 40 of these describe U.S. technologies. U.S. National Team members recommend opics and provide supporing infomation for the preparation of these brochures. Brochures come in tro different formats. Demonstration brochures contain preliminary results of a contain a full range of information on a technology. A listing of the brochure number, vise country of origin, and the title of the brochure for CADDET Demonstration Brochures and CADDET Results Brochures is available.

\section{Complimentary copies}

arailable from:

Melissa Yoss, Energy Division

Oak Ridge National Laboratory

Oals Ridge, TN $37831-6070$

Telephone: $423-574-1013$

E-mail: rossmk@oml.gov

Return to the CADDET Home Page

\section{CADDET Results Brochures}

Result 1 NETTHERLANDAN

Mechanical Yapour Recompression in an Evaporative Unit

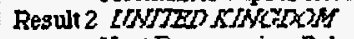

Result Heat Recovery in a Bakery

Climate Control in a Cheese Warehous

Result 4 CTMTTED ATTA TEST

Energy Management Program at the World Bank
Result 5 NETTKERLANDS

Result 5 NETHRRLLANDN

Yentilation Heat Recovery in Social Housing

Result 6 CINTJED STTATES

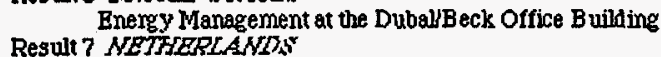

Resull

Heat Recovery at a Flower Bulb Processing Plant

Ceramic Recuperabr Recovers Heat from Exhaust Gas Result 9 FINLAND

High Speed Technology Provides Oil Free Compressors
Result 10 MSPFH

Reducing Whey using Mechanical Yapour Recompression
Result 11 sWFRER

Result 12 wage Water as a Heat Sounce for a District Heating System

Result 13 energy Consumption can be Halved in Commencial Property

Rosul 13 singen

Result 14 OEWs Cleaning and Production of Electric Powrer and Heal

Resul

Result 15 Defulation in Waste Water Treament Plant

Additional Extemal Insulation of Apartment Blocks

Result 16 STHERON

Heat Pump using Sewage Warer as a Heat Sounce

Saving of Energy in Factories for Porcelain

Wood Chip and Bark Fueled District Heating Plan

Result 19 STITTEON

Result 20 STFFEDEN

Drying Paper wilu Infrared Radiation

Result 21 LINITZZD STTATESY

Federal Methanol Fleet
Result 22 [NIJTED STTATISS

Ind uction Heating and Melting

Result 23 CINTTZD NTTATEA

Foam Processing
Result 24 NETHERLANDN"

space Heating with Cogeneration of Five Apartment Blocks

Result 25 NOPSESAY

Electricity Production by Heat Recovery at a Femosilicon Plant Result 26 DENMARK

Considerable Savings in
Result 27 NETSRRRLAMDS

Heat Recovery in the Chemical Industry
Result 28 . SFFTTZZRLAND

Heat Recovery from Yapours 
Fig. 7

\section{CADDET ANALYSIS REPORTS OCTOBER 1995}

CADDET Analysis Repors provide in-depth assessments of selected energy-saving technologies. Using examples of successful, demonstrated energy-saving projects from around the world, the reports enable the reder of benefil quickly from the many lessons leamed. The goal is to foster well infomed decision making

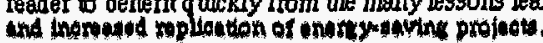

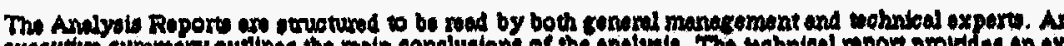

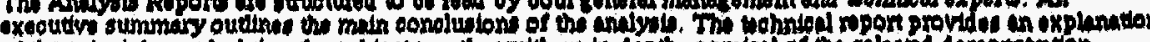

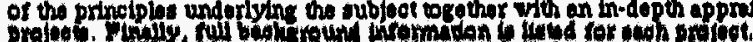

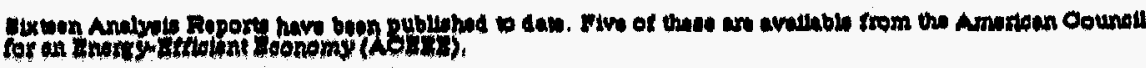

- Small-scels Coganamation

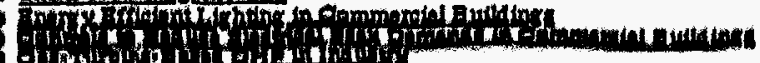

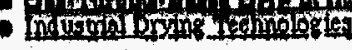

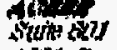

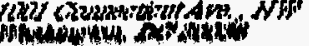

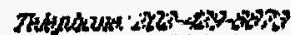

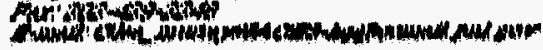

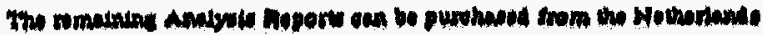

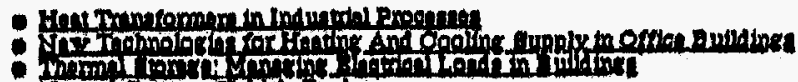

Nementong

Enerex Bficient Retrod ditus of Ofoce Bullatings

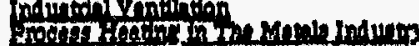

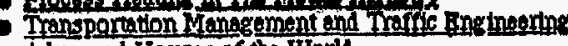

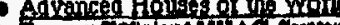

Orfores puithinge

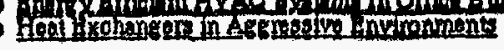

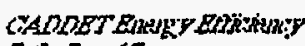

arous

The Nathesenter
Fig. 8

\section{Industrial Drying Technologies}

Ind ustrial drying is an important component of many manufacturing processes. The energy intensive nature of

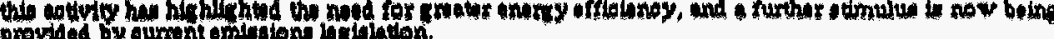

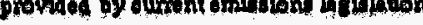

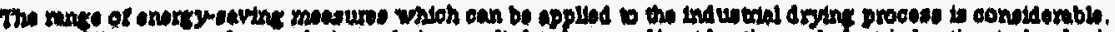

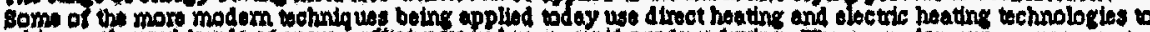

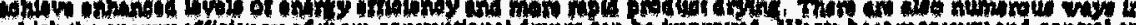

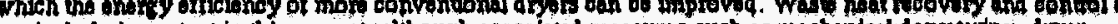

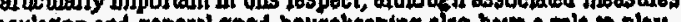

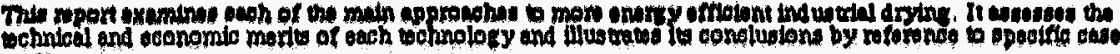
studies.

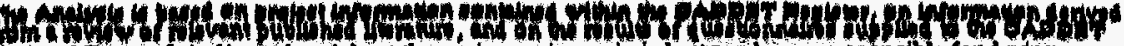

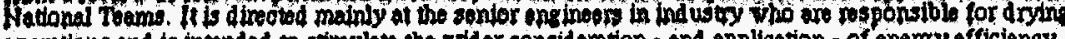
operations and is intended to sumulate the vider consideration - and applieation - of energy efficiency

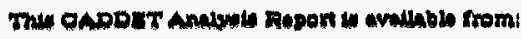

ACFRER

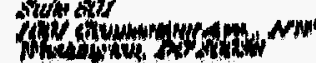

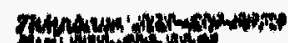

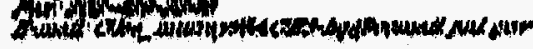

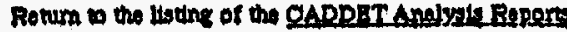



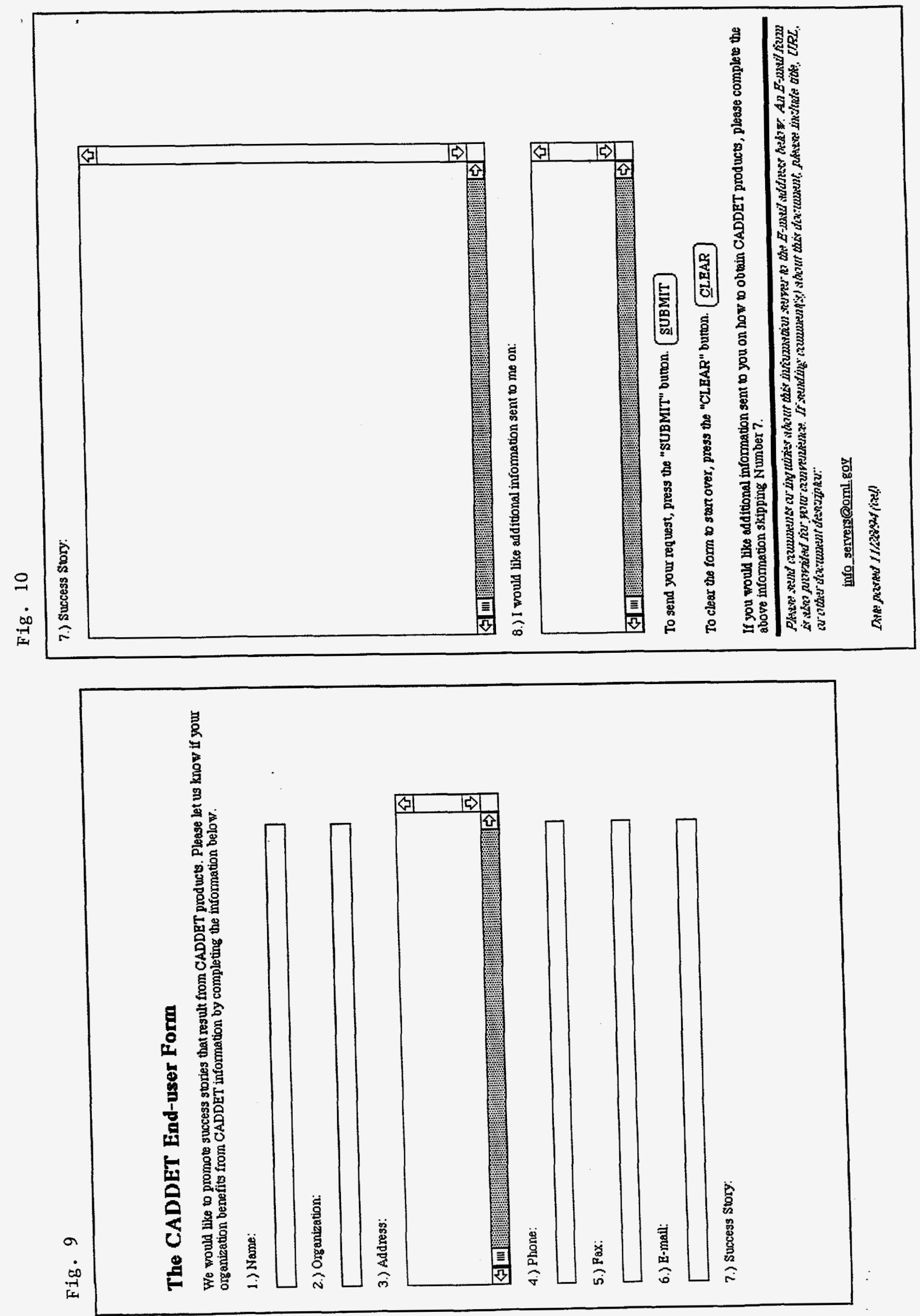


\section{USERS OF THE U.S. CADDET HOME PAGE}

From January 1, 1995, to December 31, 1995, there have been more than 10,000 "hits" on the U.S. CADDET home page system. These "hits" have increased from approximately 550 in Janxary to 1200 in December. The steady growth in the usage of the U.S. CADDET home page is shown in Figure 11.

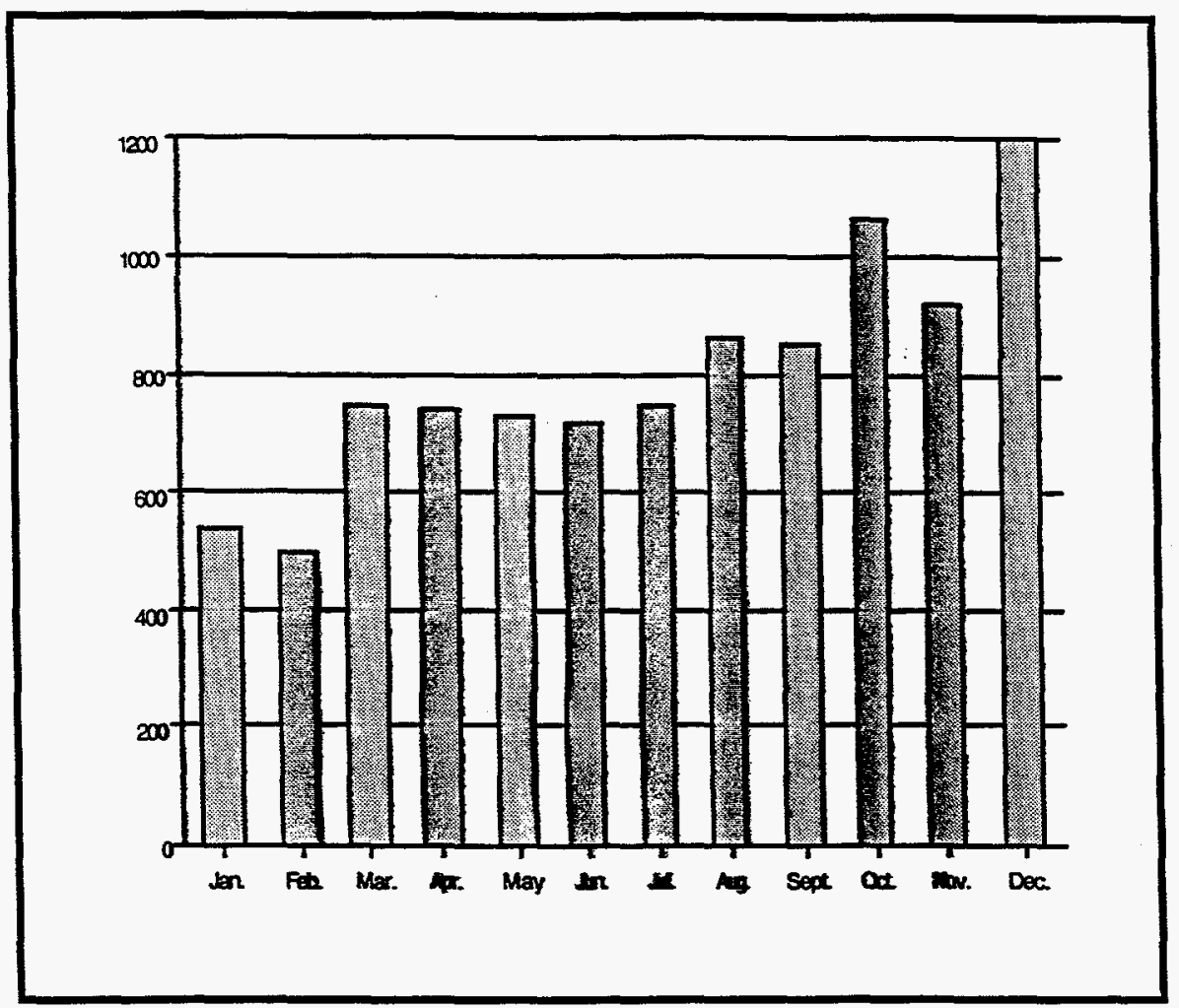

Figure 11. "Hits" on the U.S. CADDET Home Page in 1995

More than three-quarters (specifically, 4,703) of these hits were from the United States, and 1,371 , or $23 \%$, were from other countries. Countries accessing the home page span the globe, but the greatest mumbers of users outside of the U.S. are from Canada and Europe.

Table 1 presents the number of hits on the US. CADDET home page by country in December 1995. Countries are divided into three categories, based on the classification developed by Nazem (1995) to reflect word telecommmications infrastructure. "Industrialized Countries" lead the development and deployment of modern communication technology on the domestic front, and they provide both capital and know-how to facilitate infrastructure development in countries abroad. "Countries of Eastern Europe and the former Soviet Union" enjoy a high degree of literacy and have seen considerable technological growth, but they suffer from historical obstacles to the 
free flow of information. The third group of countries ("Developing Countries") is perhaps the most diverse group, and it contains some of the world's most populous and rapidly growing countries that will be accounting for an increasing share of the world's energy consumption. It is comprised of countries that currently lag furthest behind in telecommunications infrastructure and have insufficient resources to invest in significantly upgrading this infrastructure in the near term.

Table 1. "Hits" on the U.S. CADDET Home Page, by Country, in December 1995*

\begin{tabular}{|c|c|c|c|c|c|}
\hline \multicolumn{2}{|c|}{$\begin{array}{l}\text { Industrialized } \\
\text { Countries }\end{array}$} & \multicolumn{2}{|c|}{$\begin{array}{l}\text { Countries of Eastern } \\
\text { Europe and the } \\
\text { Former Soviet Union }\end{array}$} & \multicolumn{2}{|c|}{$\begin{array}{l}\text { Developing } \\
\text { Countries }\end{array}$} \\
\hline Australia & 15 & Slovenia & 5 & Indonesia & 2 \\
\hline Belgium & 2 & & & Malaysia & 2 \\
\hline Canada & 61 & & & Mexico & 7 \\
\hline Denmark & 21 & & & & \\
\hline Finland & 7 & & & & \\
\hline Germany & 2 & & & & \\
\hline Japan & 6 & & & & \\
\hline Netherlands & 14 & & & & \\
\hline Norway & 43 & & & & \\
\hline Portugal & 1 & & & & \\
\hline Spain & 6 & & & & \\
\hline Sweden & 3 & & & & \\
\hline Switzerland & 16 & & & & \\
\hline United Kingdom & 21 & & & & \\
\hline United States & 724 & & & & \\
\hline Total & 942 & Total & 5 & Total & 11 \\
\hline
\end{tabular}

*In addition, Brazil accounts for three hits, Israel for two hits, and South Africa for three hits. The location of these countries in the classification by Nazem (1995) is unclear. Further, the country origin of 234 hits during December 1995 could not be determined.

The results shown in Table 1 (and statistics on users from previous months) suggest that users in industrialized countries are accessing the U.S. CADDET information much more extensively than are users elsewhere in the world. Thus, overall these statistics indicate that the CADDET databases on the Internet can reach a large number of users with information about energy-efficient technologies. However, these same statistics also underscore the need to supplement the Internet with other forms of outreach that better meet the needs of users in countries of Eastern Europe, the Former Soviet Union, and the developing world. 
Affiliations for 719 of the 724 United States users (in December 1995) could be determined from their e-mail address extensions. Government agencies account for more than a third $(37 \%)$ of the users. However, if the usage of just one of these organizations is removed (the 105 hits from the National Renewable Energy Laboratory), this percentage drops substantially to $27 \%$. The next most frequent users are commercial organizations, which comprise $30 \%$ of the users in December. Educational institutions account for $15 \%$, and non-profit organizations account for $2 \%$. The remaining $16 \%$ of the users accessed the U.S. CADDET home page via a network service, which does not allow identification of organizational affiliations.

To the extent that these affiliations are representative of both international and domestic users, we can conclude that U.S. CADDET home page is being used by many of the audiences that are being targeted. However, it is also likely that small, resourceconstrained businesses, educational organizations, government agencies, and non-profit organizations are under-represented within the large categories of users described above.

A recent survey of Internet users in North America found that Web users typically are upscale ( $25 \%$ have incomes of more than $\$ 80,000)$, educated ( $64 \%$ with at least college degrees), and professionals (50\% are professional or managerial) (Nielsen Media Research, 1995). These same segments are likely to be more receptive than many other groups to information about newly demonstrated energy efficiency technologies. However, until the Internet has penetrated beyond these early adopters to broader segments of the population, the Internet will only partially meet the marketing needs of CADDET. As Hummel (1995, pp. 1-2) concluded in his analysis of the potential for utilities to provide customer services and marketing on the Internet, "Radio, television, telephone, print advertising, and mail service are still the predominant media for communicating with customers, [although] the technology of inter-networked computers is promising to make a quantum leap in usage."

\section{TYPES OF INFORMATION ACCESSED BY USERS}

The nature of the information accessed by users in December 1995 is portrayed in Figure 12. This graphic indicates that many users are probing the CADDET information in considerable detail. 


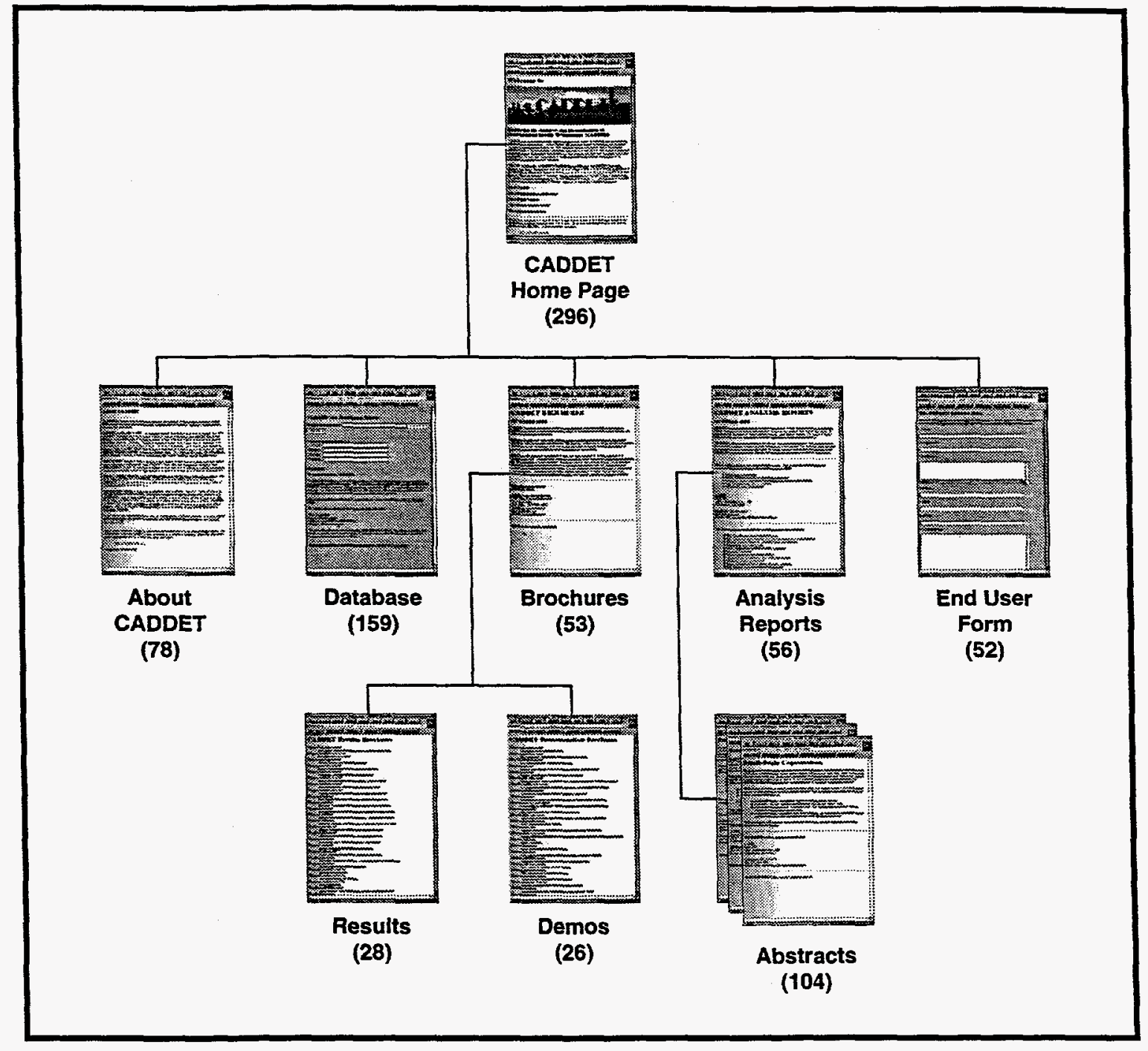

Figure 12. "Hits" on the U.S. CADDET Home Page System, in December 1995

Most users probably entered the CADDET home page system by first opening the home page. (If a user had previously opened this home page and moved on to other pages of CADDET information, they might choose to mark one of these subsequent pages-such as the one that enables database searches-and return to it when they next seek CADDET information. This is likely to become more prevalent as users become more familiar with CADDET.)

From the home page, 78 links were made to "About CADDET," 159 links were made to the CADDET database, 53 to the overview of brochures, 56 to the list of analysis reports, and 52 to the end-user form. Many users went beyond these pages to examine the titles of brochures and the abstracts of analysis reports (Table 2). In 
addition, 3 individuals completed the end-user form.

Table 2. "Hits" on Abstracts of CADDET Analysis Reports During December 1995

\begin{tabular}{|c|l|c|}
\hline Report No. & \multicolumn{1}{|c|}{ Report Title } & No. of Hits \\
\hline 1 & Small-Scale Cogeneration (revised) & 17 \\
\hline 2 & Heat Transformers in Industrial Processes & 5 \\
\hline 3 & $\begin{array}{l}\text { New Technologies for Heating and Cooling Supply in Office } \\
\text { Buildings }\end{array}$ & 6 \\
\hline 4 & Thermal Storage: Managing Electrical Loads in Buildings & 4 \\
\hline 5 & Compressed Natural Gas as a Vehicle Fuel & 4 \\
\hline 6 & Energy Efficient Lighting in Commercial Buildings & 11 \\
\hline 7 & $\begin{array}{l}\text { Controls to Reduce Electrical Peak Demands in Commercial } \\
\text { Buildings }\end{array}$ & 10 \\
\hline 8 & Energy Efficient Retrofitting of Office Buildings & 6 \\
\hline 9 & Gas-Turbine-Based CHP in Industry & 4 \\
\hline 10 & Industrial Ventilation & 4 \\
\hline 11 & Process Heating in the Metals Industry & 5 \\
\hline 12 & Industrial Drying Technologies & 5 \\
\hline 13 & Transportation Management and Traffic Engineering & 7 \\
\hline 14 & Advanced Houses of the World & 6 \\
\hline 15 & Energy Efficient HVAC Systems in Office Buildings & 6 \\
\hline 16 & Heat Exchangers in Aggressive Environments & 4 \\
\hline Total & & $\mathbf{1 0 4}$ \\
\hline
\end{tabular}

The pattern of usage shown in Table 2 suggests that many users viewed the abstract of only the first report. Further, the reports on lighting and controls in commercial buildings were of greatest interest to users in December 1995.

\section{FEEDBACK FROM USERS}

This section summarizes the information collected from those users who elected to complete the end-user form, which is an "electronic coupon" containing questions about CADDET, requests for information, and comments about the home page. As of December 31, 1995, 59 coupons were received from users in 12 different countries, with an average of approximately four coupons per month. Users from the United States constituted the largest block, comprising $70 \%$ of the total number of respondents. Other countries include Austria, Belgium, Canada, Croatia, Italy, 
Mexico, Portugal, Slovenia, South Africa, South Korea, and the United Kingdom. Most of these respondents were from the private sector $(48 \%)$ or universities $(26 \%)$.

Almost half of the individuals who completed the "electronic coupon" requested additional information about energy-efficiency $(N=15)$ or renewable energy $(N=14)$ technologies, research, or data. Another 13 individuals requested copies of specific CADDET products. The remaining respondents sought other types of information or provided comments on the U.S. CADDET home page.

\section{CONCLUSIONS}

Based on the pattern of usage of the energy-efficiency information that the United States has placed on the Internet, the authors conclude that energy efficiency information systems on the World Wide Web can contribute significantly to the goals of CADDET and other information outreach programs. The low cost of reaching large numbers of users via the Internet suggests that this information outreach tool is a costeffective mechanism. However, to reach a wider range of audiences, Internet systems need to be supplemented by other dissemination efforts aimed at reaching individuals in countries and organizations that are not currently using Internet services. In addition, more personal and customized information sources are needed to provide users with the types of assistance and guidance that may be required to translate knowledge of a technology's technical and financial performance, into a decision to adopt the technology.

\section{REFERENCES}

Hummel, P. 1995. Customer Service and Marketing on the Internet (Palo Alto, California: Electric Power Research Institute), EPRI TR-105664, November.

Nazem, S. M. 1995. "World Telecommunications Infrastructure in the Emerging Information Society," Journal of Technology Transfer, 20 (1): 23-30, April.

Nielsen Media Research. 1995. The Commercenet/Nielsen Internet Demographics Survey (Dunedin, Florida: Nielsen Media Research), October.

Verity, J., and R. Hof. 1994. "The Internet," Business Week, November 14, pp. 8088

*Managed by Lockheed Martin Energy Research Corp., for the U.S. Department of Energy under Contract DE-AC05-960R22464. 